\title{
WAYANG SILAT JAWISOGO SEBAGAI PENDIDIKAN KARAKTER CINTA TANAH AIR BERBASIS KEARIFAN LOKAL GENERASI MUDA SIDOARJO
}

\author{
Joko Susilo $^{1}$, Vidya Mandarani², Muhammad Junaedi ${ }^{3}$ \\ ${ }^{1}$ Universitas Muhammadiyah Sidoarjo. Email: jokosusilo1@umsida.ac.id \\ ${ }^{2}$ Universitas Muhammadiyah Sidoarjo. Email: vmandarani@umsida.ac.id \\ ${ }^{3}$ Universitas Muhammadiyah Sidoarjo. Email: junaedimuhammad@umsida.ac.id
}

\begin{abstract}
The aim of this community service activities is for the Kalisogo and Sidoarjo Tambak generation to generally know local wisdom, be proud of saving their culture, and increase love for the Indonesian homeland. This community service activities were carried out to remind people, especially the current generation, that in the Tambak Kalisogo there had been a heroic event about resistance to the Dutch invaders through Jawisogo Silat. The event was showed through Puppet Sarip performance that developed into Jawisogo Wayang Silat. The activity process begins with: (1) strengthening literacy about the story of the struggle in the Tambak Kalisogo, (2) with children and young people creating Jawisogo Wayang Silat characters, and (3) doing the Jawisogo Wayang Silat Wayang performance. In the next stage, the performances were started from Tambak Kalisogo Village and then to several areas in Sidoarjo. The partners in this activity are community leaders and youth of Tambak Kalisogo Village, Jabon District, Sidoarjo, East Java.
\end{abstract}

Keywords : Wayang, Silat Jawisogo, local wisdom

\begin{abstract}
ABSTRAK
Tujuan dari kegiatan pengabdian kepada masyarakat ini adalah agar generasi Tambak Kalisogo dan Sidoarjo secara umum mengetahui kearifan lokal, bangga menyelamatkan budayanya, dan meningkatkan rasa cinta terhadap tanah air Indonesia Kegiatan pengabdian kepada masyarakat ini dilaksanakan untuk mengingatkan kembali masyarakat khususnya generasi masa kini bahwa di Tambak Kalisogo pernah terjadi peristiwa heroik tentang perlawanan terhadap penjajah Belanda melalui Silat Jawisogo. Peristiwa tersebut ditampilkan melalui pertunjukan Wayang Sarip yang dikembangkan menjadi Wayang Silat Jawisogo. Proses kegiatannya dimualai dari: (1) penguatan literasi tentang cerita perjuangan di Tambak Kalisogo, (2) bersama anak-anak dan remaja menciptakan tokoh karakter Wayang Silat Jawisogo, dan (3) melakukan latihan pertunjukan Wayang Silat Jawisogo. Pada tahap selanjutnya pementasan yang dimulai dari Desa Tambak Kalisogo kemudian ke beberapa wilayah di Sidoarjo. Mitra dalam kegiatan ini adalah tokoh masyarakat dan pemuda Desa Tambak Kalisogo, Kecamatan Jabon, Sidoarjo Jawa Timur..
\end{abstract}

Kata kunci: Wayang, Silat Jawisogo, kearifan lokal

\section{PENDAHULUAN}

Tambak Kalisogo adalah sebuah desa yang terletak di Kecamatan Jabon bagian paling timur kabupaten Sidoarjo. Dikisahkan bahwa desa Tambak Kalisogo, pada masa dahulu adalah hutan belantara tanpa terdapat manusia yang menghuni. Hutan yang 
ditumbuhi tanaman, pepohonan lebat. Hutan alami belum adan kerusakan oleh perbuatan manusia. Dahulu banyak masyarakat dari desa Bangil pergi ke desa Bluru untuk bekerja. Masyarakat tersebut pergi ke desa Bluru mencari penghidupan, para pejalan kaki secara berkelompok. Karena jauhnya jarak dari desa Bangil ke desa Bluru, masyarakat itu sering melepas lelah di lokasi yang sekarah telah berubah menjadi desa Tambak Kalisogo" (Alimah, 2019).

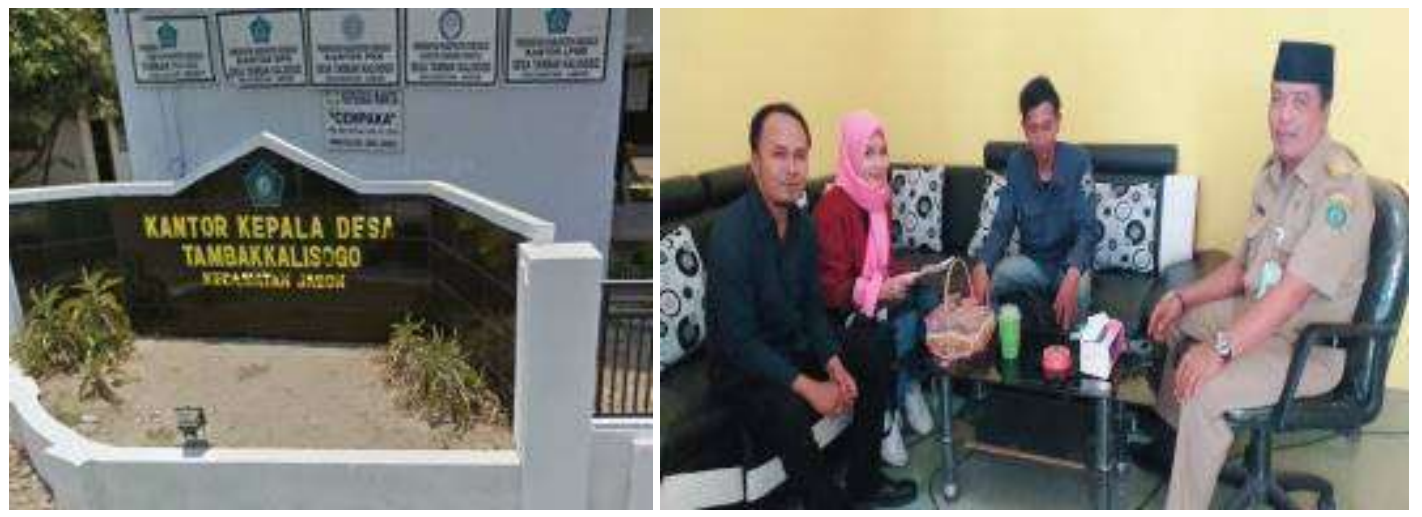

Gambar 1. Dosen dan mahasiswa Umsida melakukan pendekatan kepada mitra di Desa TambakKalisogo.

Pada masa penjajahan Belanda permasalahan timbul di wilayah Tambak Kalisogo. Hutan itu dieksploitasi untuk memenuhi berbagai kebutuhan Belanda. Terjadilah perlawanan oleh para jagoan Kalisogo kepada kezaliman Belanda. Peperangan ini oleh beberapa tokoh masyarakat dikenal dengan nama Silat Jawisogo ("Silat"yang berarti Perang, dan "Jawisogo" yang berarti masyarakat desa Tambak Kalisogo), dipimpin oleh tokoh-tokoh adat atau yang lebih dikenal sebagai pepadu-pepadu Silat Jawisogo.

Desa Tambak Kalisogo harus mampu mempunya karakter atau jati diri sebagai desa yang berbudaya. Generasi desa harus mendapatkan ilmu pengetahuan dari kearifan lokal desanya yang merupakan kebudayaan murni negeri lndonesia. Pudarnya pemahaman tentang kekayaan lokalitas harus dihindari dan ditangani dengan kegiatan positif. Ketika nilai lokal itu pudar berdampak pada pudarnya rasa bangga terhadap budaya aslinya, ditakutkan akan melemahkan rasa cinta tanah air. Melalui sosialisai dan pengenalan wayang yang merupakan budaya asli lndonesia: dikreasikan seni tradisi dan modern ditujukan supaya anak-anak dan remaja dapat menyerap, mempraktikkan nilai-nilai kearifan lokal (Darusman, 2016).

Permasalahan yang akan diselesaikan adalah permasalahan umum generasi masa kini yang kurang peduli dengan lingkungan dansosialnya. Prioritas program ini adalah dengan dihadirkannya Wayang Silat Jawisogo ini dapat membentuk karakter cinta tanah air generasi yaitu dimulai dengan kepedulian lingkungan dan sosial. Kecintaan yang terbentuk nantinya diharapkan dapat mendukung visi antibegal di Tambak Kalisogo dan Jabon pada umumnya. 


\section{METODE PELAKSANAAN}

\section{A. Pencarian Referensi Muatan sejarah lisan "Silat Jawisogo"}

Kisah Silat Jawisogo mempunyai kemiripan nafas dengan kisah Sarip Tambak Oso, yaitu tentang perlawanan terhadap penjajahan dan ketidak-adilan, Perlawanan terhadap segala ancaman terhadap kelestarian negeri atau tanah air. "Seorang tokoh Silat Jawisogo dulu sebagai pembabat hutan Kalisogo bernama Raden Surya Agung. Walaupun tanpa alas kaki, Ia bahkan tidak tertusuk duri sekalipun. Raden Surya Agung menebang pohon mengubah wilayah tersebut menjadi pertanian dan lahan perkampungan" (Alimah, 2019). Semangat perjuangan tokoh silat inilah yang membengkitkan seluruh warga Tambak Kalisogo untuk melawan penjajah. Lanjutan wawancara di atas mengatakan bahwa para pribumi berhasil mengalahkan para penjajah.

Kisah Silat Jawisogo mempunyai kemiripan dengan kisah Sarip Tambakoso oleh Djamil Suherman (1985). Buku tersebut juga berkisah tentang perjuangan Sarip Tambak Oso seorang anak yang sangat berbakti pada ibunya. Sarip gigih melawan Belanda selaras dengan kegigihan Kang Mas Adipati Reksa, Raden Surya Agung, bersama warga Tambak Kalisogo melawan penjahahan Belanda. Mitologi Jawa mempunyai hakikat sebagai suatu dasar budaya masyarakat Jawa dalam upaya menyelesaikan permasalahan kehidupan (Zaidan, 2002).

\section{B. Pembuatan dan Pewarnaan Wayang}

Karakter Wayang Silat Jawisogo dibuat bersama antara tim dari Umsida dengan anak-anak dan remaja desa Tambak Kalisogo. Wayang tersebut terbuat dari kulit, mika, dan kertas art karton tebal 300gsm. Selanjutnya wayang diwarnai dengan beberapa warna yang meriah bagi anak-anak supaya mereka bisa tertarik ketika dipertontonkan.
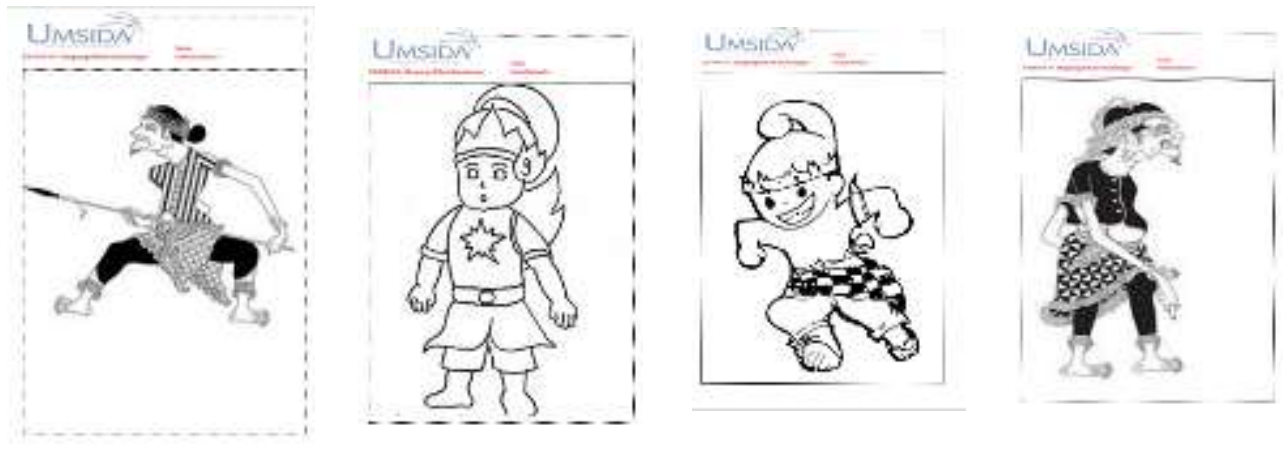

Gambar 2. Desain Wayang Untuk diwarnai Anak-anak

\section{Praktik Pementasan}

Praktik yang dilakukan dalam pementasan Wayang Silat Jawisogo dimulai dengan olah gerak wayang dan bahasa wayang. Wayang dua dimensi tidak bisa menggerakkan mulut ketika berucap sehingga tangan yang berperan. Iringan pertunjukan adalah irama macapat, karawitan (gamelan), dan irama musik modern. Keserasian irama macapat berfungsi sebagai pembangun karakter nada yang serasi dengan olah rasa filosofi Jawa. Macapat meemiliki aturan bunyi, baris dan suara yang disebut guru gatra: cacah gatrane sekar (jumlah baris pada satu bait), guru lagu: dhingdhonging suwara ing wekasan gatra sekar (bunyi pada terakhir baris), guru wilangan: 
cacah wanda gatra-gatrane sekar (banyaknya sukukata setiap baris) (Susastina, 2009:3).

Pertunjukan awal dilakukan dilakukan di tempat-tempat strategis desa Tambak Kalisogo. Pertunjukan di tempat pertama dilakukan langsung oleh tim dari Universitas Muhammadiyah Sidoarjo. Pada tahap selanjutnya penonton (remaja dan anak-anak) dimintai kesan komentar tentang muatan nilai positif lokalitas yang dapat digunakan sebagai pendidikan karakter luhur. Pertunjukan kedua melibatkan remaja dan siswa TK$\mathrm{SD}$, tujuannya adalah utuk semakin mendekatkan diri dengan budaya: semakin dekat semakin cinta.

Pertunjukan tersebut disajikan menggunakan bahasa Jawa sederhana yang biasa didengarkan masyarakat Sidoarjo, (basa arek nDarjo). Bahasa Jawa baku adalah bahasa mataraman (Solo-Jogja), sementara itu masyarakat Surabaya-Sidoarjo menggunakan karakter bahasa arekan. Dapat disimpulkan bahasa arekan adalah bahasa Jawa pesisiran. Bahasa Jawa pesisiran merupakan kalimat dan kosakata yang dimiliki orangorang Jawa di wilayah pesisir utara nusa Jawa (Hutomo, 1984).

\section{Evaluasi dan Promosi}

Evaluasi ini ditujukan kepada mitra yaitu anak-anak TK dan remaja Karangtaruna. Tujuannya adalah untuk mengetahui tingkat kepemahaman terhadap makna kisah cerita rakyat Silat Jawisogo, untuk mengetahui tingkat kecintaan dan kepercayaandirinya terhadap budaya Kalisogo. Jika kecintaan dan kepercayaan diri tersebut telah meningkat akan dipupuk untuk semakin cinta tanah air lndonesia. Tahap lanjutannya adalah tim pengabdian masyarakat akan menyebarluaskan kearifan lokan Silat Jawisogo ke masyarakat Sidoarjo secara umum.

\section{HASIL DAN PEMBAHASAN}

Kegiatan ini diawali dengan konsentrasi khusus bagi generasi muda di Desa Tambak Kalisogo, selanjutnnya diterapkan juga bagi anak-anak dan remaja di Sidoarjo secara umum. Tim pengabdian berupaya menyebarluaskan kecintaaan generasi muda terhadap kearifan lokal wayang kulit dan Wayang Silat Jawisogo.

Pengabdian kepada masyarakat Wayang Silat Jawisogo yang seharusnya dilakasanakan pada bulan Maret dan April 2020, namun mengalami hambatan karena adanya wabah dunia yaitu Comvid-19. Kegiatan yang ditekuni untuk mengatasi masalah-masalah tersebut adalah dengan dilakukannya modifikasi supaya tertib terhadap hanjuran pemerintah tentang social distancing dan physical distancing.

Kegiatan pembuatan dan pewarnaan wayang dilakukan secara terpisah di rumah masing-masing. Kegiatan latihan pertunjukan dilakukan dengan maksimal menghadirkan 3 orang anak, dimulai dengan mencuci tangan dengan sabun dan air mengalir, latihan pun tidak boleh berhimpitan. Kegiatan pertunjukan Wayang Silat Jawisogo yang seharusnya mengumpulkan banyak orang dimodifikasi dengan kegiatan mendongengkan kisah Silat Jawisogo: satu pencerita, satu pendengar. Kegitan mendongeng ini dilakukan oleh 10 mahasiswa Umsida yang lokasinya bermacammacam wilayah Sidoarjo. 


\section{A. Pewarnaan dan Pembuatan Wayang}

Upaya untuk mengenalkan mencintai wayang kepada anak-anak diawali dengan mewarnai wayang. Sidoarjo mempunyai warna karakter budaya yang kuat mulai dari sejarah Jenggala, Majapahit sampai masa perlawanan terhadap penjajahan Belanda (Susilo, Suwarta, \& Taufiq, 2019). Kondisi generasi desa Tambak Kalisogo saat ini sudah semakin jauh dari pengetahuan budaya lokal yang sesungguhnya berpotensi sebagai pembentuk karakter cinta tanah air lndonesia. Berikut adalah pendekatan budaya bagi anak-anak generasi Sidoarjo supaya semakin cinta terhadap kekayaan lokal pengetahuan luhut. Dimulai dari mewarnai wayang, latihan pertunjukan wayang, sampai bercerita atau mendongeng kisah-kisah Wayang Silat Jawisogo.

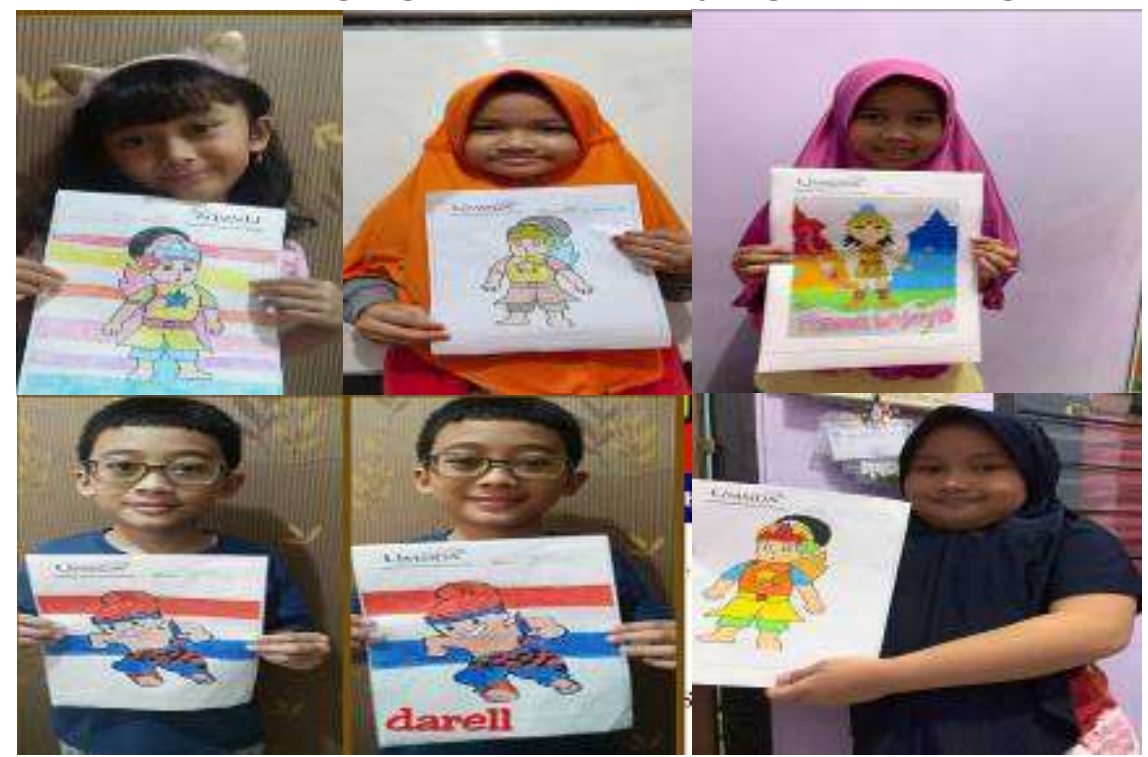

Gambar 3. Hasil Pewarnaan Wayang oleh Anak-anak Sidoarjo

Pewarnaan dilakukan pada awal April 2020 oleh anak-anak dari berbagai sekolah di Sidoarjo: Devina dari TK Al-Furqon, Kayla dari MINU KH. Mukmin, Adya Khansa dari SD Muhammadiyah 1, Darell dari SD Muhammadiyah 1 dan Adiv dari TK Al-Furqon. Mereka memilih karakter wayang yang disukai selanjutnya mereka mendapatkan cerita tentang kisah heroik Silat Jawisogo. Pada tahap ini diharapkan anak-anak mengenal wayang dengan cara mewarnai wayang-wayang yang didesain disesuaikan dengan karakter anak, dengan tidak meninggalkan karakter wayang.

\section{B. Pembuatan Wayang}

Pembuatan wayang dilakukan pada bulan Februari sampai Maret 2020 oleh Muhammad Sigit Herdianto (dalang muda mahasiswa Universitas Muhammadiyah Sidoarjo) berdasarkan tokoh dan karakter yang disusun oleh Joko Susilo (dosen Universitas Muhammadiyah Sidoarjo) dan Fahim Rido (remaja dari desa Tambak Kalisogo, mahasiswa Universitas Muhammadiyah Sidoarjo). Wayang karakter Silat Jawisogo didesain dengan warna yang ceria supaya disukai anak-anak. Wayang ini terbuat dari kulit dan ada yang terbuat dari plastik.

Berikut adalah proses pembuatan dan hasil bentuk wayang. Wayang yang dipeerkenalkan kepada anak-anak bukan hanya wayang kreasi Silat Jawisogo tetapi 
secara umum wayang purwa juga diperrkenalkan kepada anak-anak, dengan model modifikasi kekinian.
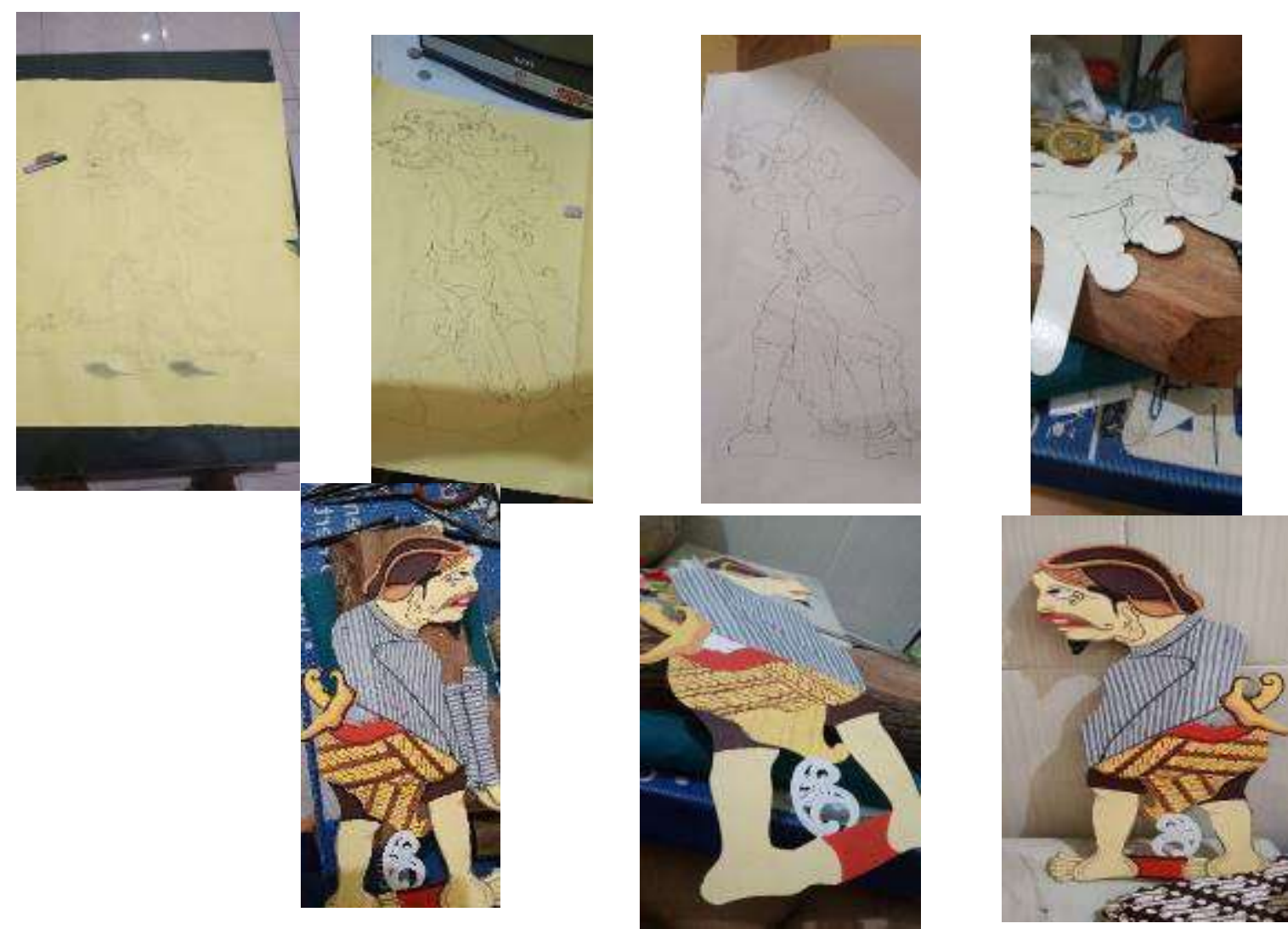

Gambar 4. Proses Pembuatan Wayang Karakter Silat Jawisogo

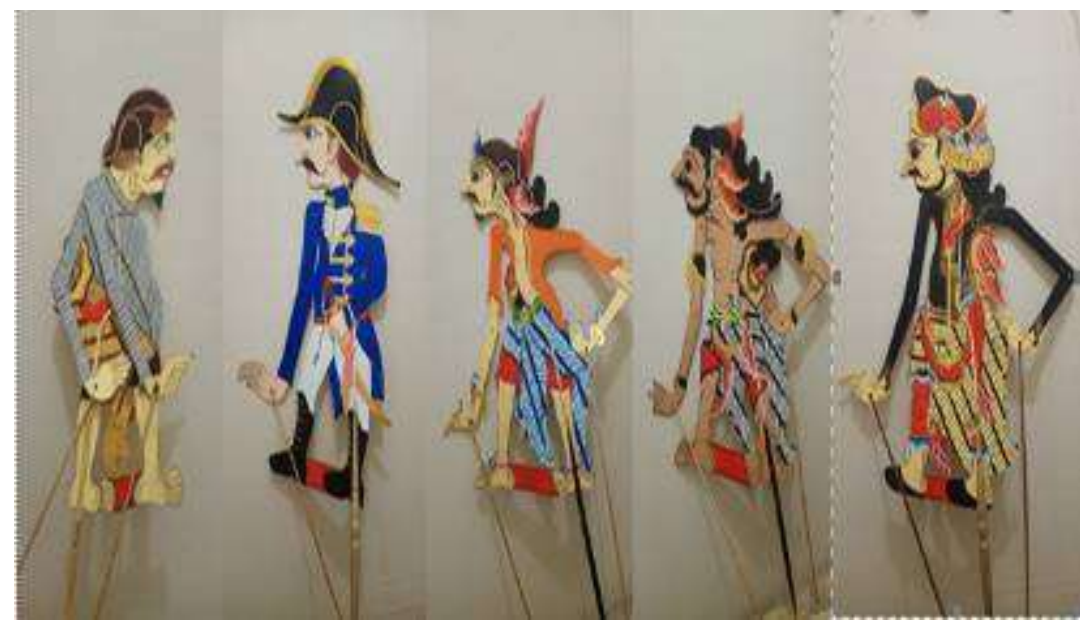

Gambar 5. Hasil Jadi Wayang Karakter Silat Jawisogo

\section{Praktik Pementasan}

Tahap praktik pementasan dilakukan dengan latihan bersama beberapa anak maksimal menghadirkan 3 orang anak, dimulai dengan mencuci tangan dengan sabun dan air mengalir, latihan pun tidak boleh berhimpitan. 


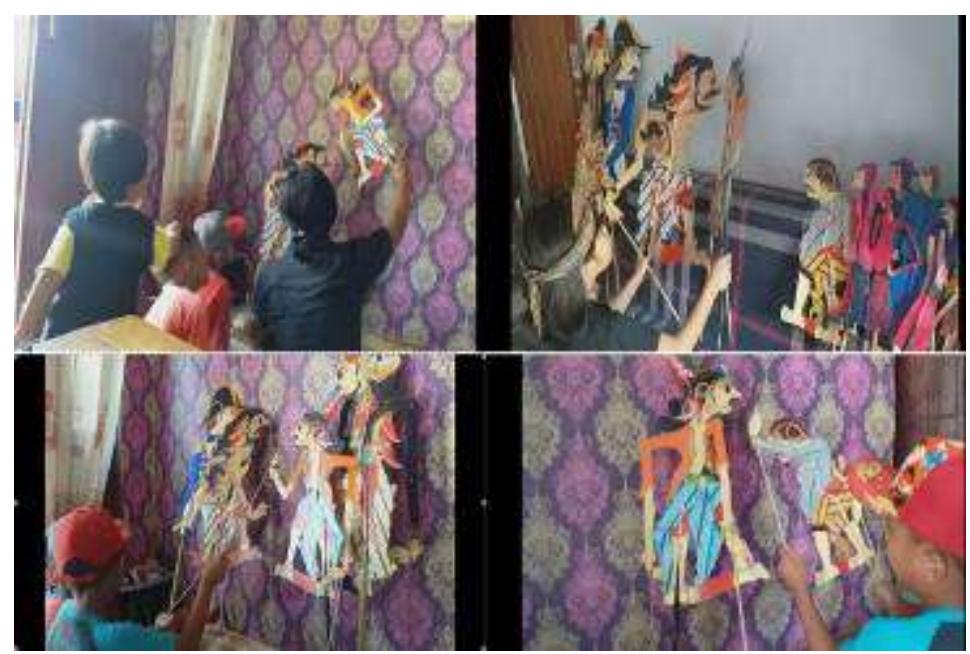

Gambar 6. Praktik Pementasan

Praktik pementasan ini meliputi latihan menggerakkan wayang dan latihan penggunaan bahasa atau dialog wayang. Bahasa yang digunakan adalah bahasa Jawa sederhahana yang dapat dipahami oleh anak-anak dan remaja di Sidoarjo, dan disisipkan tata krama bahasa Jawa misal tokoh yang berusia muda (Kang Mas Adipati Reksa) menggunakan bahasa krama kepada tokoh yang tua (mbah Supomo). Latihan penekanan bahasa juga penting misalnyanya kalimat perintah dan kalimat tanya. Pengetahuan fungsi kalimat penting diperhatikan oleh seorang penutur (Dalang). Mitra tutur harus dapat menangkap bentuk perintah dari penutur (Hasanudin, 2018)

\section{Sosialisasi Kisah Silat Jawisogo}

Kegiatan sosialisasi Wayang Silat Jawisogo dilakukan dengan kegiatan mendongengkan kisah Silat Jawisogo: satu pencerita dengan maksimal 4 pendengar. Anak-anak sebagai pendengar harus menjaga jarak dan mencuci tangan dengan sabun dan air mengalir. Kegitan mendongeng ini dilakukan oleh 10 mahasiswa Umsida yang lokasinya bermacam-macam wilayah Sidoarjo. Di bawah ini adalah beberapa dokumentasi kegiatan sosialisasi cerita Silat Jawisogo:

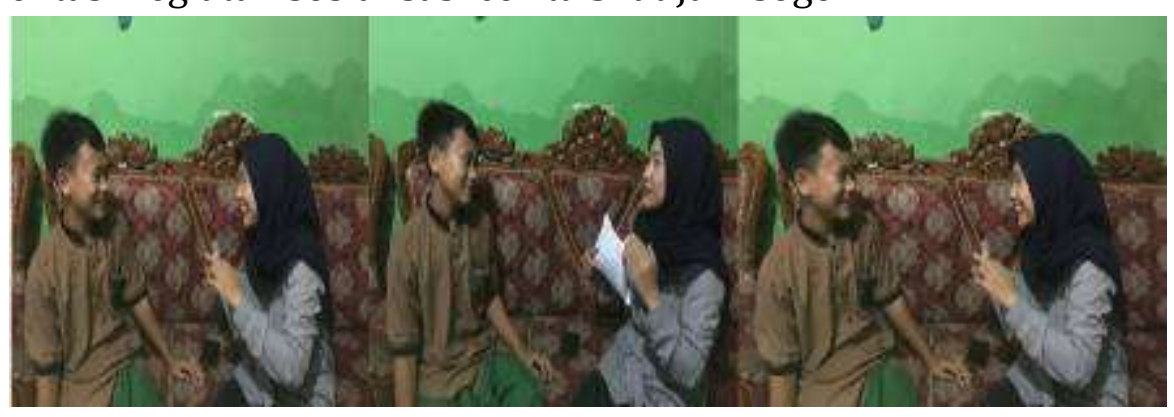




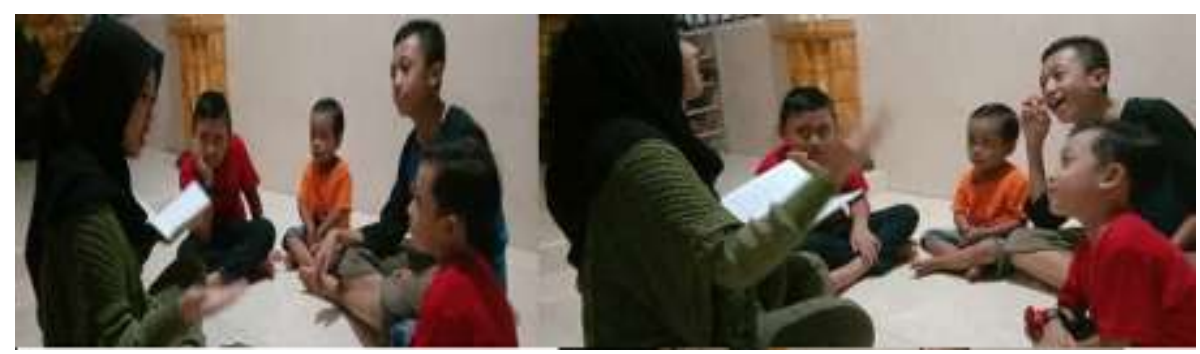

Gambar 6. Mendongeng oleh Melinda Indira Jati kepada Haikal Indra Jati (12 tahun), Gibran Putra Sutrisno (3 tahun), Naufal Khaila Azzar (6 tahun), dan Bagus Sajiwo (8 tahun)

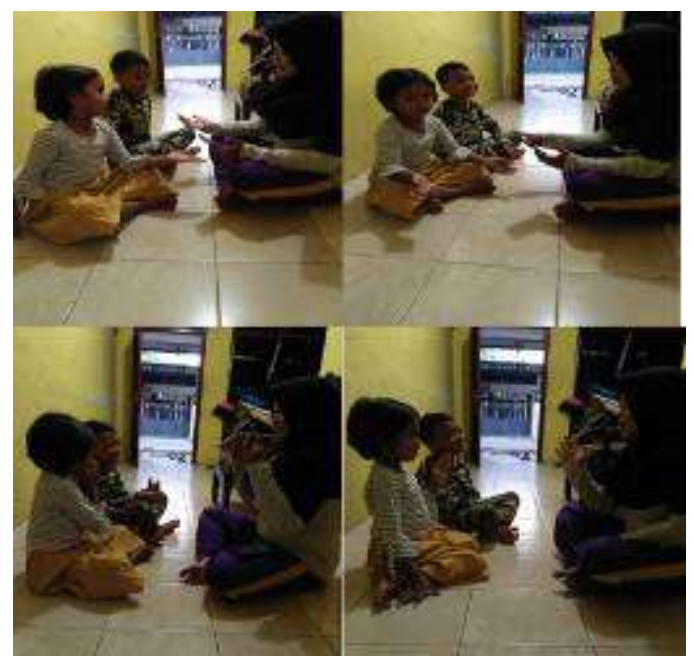

Gambar 6.

Mendongeng oleh Yofi Citra Agustina kepada Kian Igustian (7 tahun) dan Nayla Anindytha (5 th) di Klantingsari Tarik, Sidoarjo

Dongeng kisah Silat Jawisogo bermanfaat juga sebagai pengisi kegiatan anakanak selama social distancing dan physical distancing. Mereka di rumah belajar tentang pengetahuan wayang, cerita rakyat dan diharapkan semakin cinta dengan tanah air Indonesia. Salah satu contoh kegiatan mendongeng dapat disaksikan pada alamat website youtube: https://www.youtube.com/watch?v=wPQsiRXc3o8

Kisah silat Jawisogo yang berasal dari desa Tambak Kalisogo merupakan potensi lokal Sidoarjo yang dapat menjadi penguat karakter luhur generasi muda dan penguat promosi wisata berbasis kearifan lokal. Setiap tahun Umsida selalu mengirimkan mahasiswa KKN ke wilayah Tambak Kalisogo sampai Tlocor. Kegiatan tersebut dalam upaya meningkatkan kualitas mahasiswa dan masyarakat setempat yang mempunyai potensi wisata Tolocor sampai Pulau Lusi. Hadirnya kisah-kisah lokal seperti cerita silat Jawisogo dapat menjadi daya tarik promosi wisata.

\section{SIMPULAN}

Pengabdian kepada masyarakat berjudul "Bangkitkan Wayang Silat Jawisogo Di Desa Tambak Kalisogo Sebagai Pemupuk Rasa Cinta Tanah Air Generasi Muda”. Kegiatan ini dilakukan oleh 3 (tiga) orang dosen Universitas Muhammadiyah Sidoarjo selama 4 bulan yaitu mulai Januari sampai April 2020. Pengabdian tersebut merupakan lanjutan 
dari kegiatan sosialisasi wayang Sarip pada tahun 2017, dan merupakan satu rangkaian gagasan tentang upaya pelestarian kearifan lokal dan diterapkan kepada genersai muda. Pada kegiatan ini upaya yang dilakukan adalah penguatan pengetahuan bahwa desa Tambak Kalisogo menyimpan kisah heroik perlawanan terhadap penjajah Belanda melalui Silat Jawisogo. Peristiwa tersebut akan ditampilkan dalam bentuk Wayang Silat Jawisogo. Proses kegiatannya dimualai dari: (1) penguatan literasi tentang cerita perjuangan di Tambak Kalisogo, (2) bersama anak-anak dan remaja menciptakan tokoh karakter Wayang Silat Jawisogo, dan (3) melakukan latihan pertunjukan Wayang Silat Jawisogo. Pada tahap selanjutnya akan dipentaskan dimulai dari Desa Tambak Kalisogo selanjutnya ke beberapa wilayah di Sidoarjo. Mitra dalam kegiatan ini adalah tokoh masyarakat dan pemuda Desa Tambak Kalisogo, Kecamatan Jabon, Sidoarjo Jawa Timur. Hasil akhir dari program ini adalah generasi Tambak Kalisogo dan Sidoarjo secara umum mengetahui kearifan lokal, bangga menyelamatkan budayanya, dan meningkatkan rasa cinta terhadap tumpah darahnya.

\section{UCAPAN TERIMA KASIH}

Tim pengabdian masyarakat Wayang Silat Jawisogo menghaturkan terima kasih yang sebesar-besarnya kepada DRPM Universitas Muhammadiyah Sidoarjo. Kedua ucapan terima kasih kami haturkan kepada tokoh masyarakat dan pemuda desa Tambak Kalisogo, terimaksih yang sebear-besarnya kepada seluruh mahasiswa Umsida yang membantu dengan sepenuh hati.

\section{DAFTAR RUJUKAN}

Alimah. (2019). Wawancara tokoh masyarakat Kalisogo tentang asal-usul desa [Interview] (10 November 2019).

Darusman, Y. (2016). Kearifan lokal kerajinan bordir Tasikmalaya sebagai ekonomi kreatif terbuka untuk modern. Journal of Nonformal Education, 2(2), 107-119.

Hasanudin, C. (2018). Kajian Sintaksis pada novel Sang Pencuri Warna karya Yersita. $\begin{array}{llll}\text { Jurnal Pendidikan Edutama, 5(2), } & \text { 19-30. }\end{array}$ http://dx.doi.org/10.30734/ipe.v5i2.191

Hutomo, S. S., et all. (1984). Penelitian bahasa dan sastra Babad Demak Pesisiran. Jakarta: Pusat Pembinaan dan Pengembangan Bahasa Departemen Pendidikan dan Kebudayaan.

Suherman, D. (1985). Sarip tambak-oso (Kisah kasih seorang ibu). Jakarta: Mizan.

Susastina, S. (2009). Tembang macapat. Yogyakarta: Panji Pustaka.

Susilo, J., Suwarta, N., \& Taufiq, W. (2019). Representasi Kemakmuran Alam Dalam Serat Cemporet. Parafrase, 19(1), 59-64.

Zaidan, dkk. (2002). Mitologi Jawa dalam puisi Indonesia 1971 - 1990. Jakarta: Pusat Bahasa Departemen Pendidikan Nasional. 
152 J-Abdipamas, Vol. 4, No. 1 April, 2020 